\title{
In virto Propagation Response of Rosmarinus officinalis L. to Biotic and Abiotic Elicitors on Phenolic Content and Photosynthetic Pigments
}

\author{
Hadeer Yahia Darwesh ${ }^{1,2} \&$ Aisha Abdullah Alayafi ${ }^{3}$ \\ ${ }^{1}$ Biotechnology Department, Faculty of Science, Taif University, Taif, Kingdom of Saudi Arabia \\ ${ }^{2}$ Medicinal and Aromatic Plants Department, Horticulture Institute, Agricultural Research Centre, Giza, Egypt \\ ${ }^{3}$ Biological Sciences Department, Faculty of Science, University of Jeddah, Jeddah, Kingdom of Saudi Arabia \\ Correspondence: Hadeer Yahia Darwesh, Biotechnology Department, Faculty of Science, Taif University, Taif, \\ Kingdom of Saudi Arabia. E-mail: hadeer.darwesh@yahoo.com
}

Received: October 22, 2017

Accepted: December 4, 2017 Online Published: January 15, 2018

doi:10.5539/jas.v10n2p301

URL: https://doi.org/10.5539/jas.v10n2p301

\begin{abstract}
Micropropagation protocol was modified to evaluate the best procedure to induce multiple shoots from Rosmarinus officinalis L. sterilized seedlings obtained from seeds which vitality is always very low. Aseptic shoots $(1-1.5 \mathrm{~cm})$ were cultured on full strength Murashige and Skoog medium modified with several growth regulators (abiotic elicitors): Benzyladenine (BA), Kinetin (Kin) and coconut water (biotic elicitors). Data was indicated that BA at the concentration of $3 \mathrm{mg} / \mathrm{L}$ encouraged shoot multiplication. The highest number of leaves and plant length also was obtained with medium modified with $3 \mathrm{mg} / \mathrm{L} \mathrm{BA}$ and coconut milk at $5 \mathrm{ml} / \mathrm{L}$. All treatments were significantly different from the control. Total phenolics content, anthocyanins, chlorophylls were extracted and spectrophotometrically determined as secondary products. Data was concluded the highest content of phenolic $10.45(\mathrm{mg} / \mathrm{g})$ and chlorophyll b $0.67(\mathrm{mg} / \mathrm{g})$ when BA was $3.0 \mathrm{mg} / \mathrm{L}$. Whereas chlorophyll a reached to $0.64 \mathrm{mg} / \mathrm{g}$ in presence of $5.0 \mathrm{mg} / \mathrm{L} \mathrm{BA}$ and $5.0 \mathrm{ml} / \mathrm{L}$ coconut milk. Anthocyanin scored high level when BA was $3.0 \mathrm{mg} / \mathrm{L}$ combined with $5.0 \mathrm{ml} / \mathrm{L}$ coconut milk.
\end{abstract}

Keywords: Rosmarinus officinalis L., in vitro propagation, shoot multiplication, plant growth regulators, and secondary products

\section{Introduction}

Medicinal and aromatic plants play an important role in all areas of the world. The family Lamiaceae took the oral wide acclaim According to the content of a range of medicinal plants, each of which is in itself a treasure such as Rosemary. It is a perennial woody, aromatic herb, common in the Mediterranean region, but is now grown worldwide. Rosmarinus officinalis L, commonly known as rosemary, is a woody, perennial herb with fragrant, evergreen, needle-like leaves and white, pink, purple, or blue flowers. It is a member of the mint family Lamiaceae, which includes many other herbs. The name "rosemary" is derives from the Latin for "dew" (ros) and "sea" (marinus), or "dew of the sea" (Room, 1988).

The plant is also sometimes called anthos and it is a considerable source of secondary metabolites, especially essential oils, which have antiviral, antimicrobial, antispasmodic, antioxidant, diuretic, anticonvulsant, analgesic hepatoprotective, and anti-carcinogenic properties (Bozin et al., 2008; Saltan \& Ozaydin, 2013). It is also being used in cosmetic industry and food (Wang et al., 2008). The essential oil of rosemary consists of flavonoids as carnosic acid, carnasol, rosmarinic acid, and volatile oils (Okamura et al., 1994). Carnosic acid and Carnosol constitute $3.8-4.6 \%$ of the extracted material, and they are considered as constituents in rosemary that show pharmacological properties (Huang et al., 1994). Several flavonoids and phenolic compounds such as hispidulin, cirsimaritin, apigenin, genkwanin, naringin, caffeic acid and rosmarinic acid are also present in rosemary extracts (Jasim, 2017). It has been considered as one of the most effective herbs for treating inflammatory diseases, headaches, poor circulation, headaches, and physical and mental fatigue (Eilyad et al., 2012). Rosemary extracts and its components have anti-lipid peroxidant activities and free radical scavenging by various in vitro antioxidant assays (Bilto \& Alabdallat, 2015).

Due to shining virtues of rosemary and its poor seed germination $(30 \%)$, there is a need for new propagation methods which can increase its production (Nourin \& Humera, 2014). Plant tissue culture has been used as a tool 
for rapid micropropagation and, the conservation of medicinal plants and also for providing a source of secondary metabolites which has an important medical aspect such as phenolic compounds, anthocyanin and their glycosidic forms (anthocyanins) acted as strong antioxidants (Tokusoglu \& Yildirim, 2012).

\section{Materials and Methods}

This study was carried out in Plant Tissue Culture Laboratory, Faculty of Science, Taif University, Saudi Arabia during the January to March season 2016.

\subsection{Sterilization Procedure}

Seeds of $R$. officinalis L. were sterilized by washing in tap water supplemented with soap and small drops of Tween 20 , then immersed in ethanol $70 \%$ for $1 \mathrm{~min}$, washed with sterile distilled water and in $15 \%$ commercial Clorox solution for $10 \mathrm{~min}$. Seeds were washed three times with sterile distilled water in laminar air flow hood.

\subsection{Culture Media}

Sterilized seeds were cultured on (MS medium 1962). After germination, seedlings about 1-1.5 cm high also were cultured in (MS medium 1962) modified with (abiotic elicitors) Kinetin (Kin) at $0.0,3.0$, and $5.0 \mathrm{mg} / \mathrm{L}$ and, Benzyl amino purine (BA) at $0.0,3.0$, and $5.0 \mathrm{mg} / \mathrm{L}$ in addition of (biotic elicitors) $5.0 \mathrm{ml} / \mathrm{L}$ Coconut water. Sucrose was used at $30 \mathrm{~g} / \mathrm{L}$ and agar at $8 \mathrm{~g} / \mathrm{L}$. The media were distributed into sterilized jars. Each of which contained $30 \mathrm{ml}$ of MS medium. The $\mathrm{pH}$ medium was adjusted to $5.7-5.8$ before autoclaving for $15 \mathrm{~min}$ at $121^{\circ} \mathrm{C}$, $1.5 \mathrm{~kg} / \mathrm{cm}^{3}$. Jars were incubated in the growth chamber at $26 \pm 2{ }^{\circ} \mathrm{C}$ and $16 \mathrm{hr}$ light/day under constant fluorescent light of 1500 Lux.

\subsection{Experimental Treatments}

There were nine treatments; each treatment included ten jars with (three explants in each) as follows:

(1) $0.0 \mathrm{mg} / \mathrm{L} \mathrm{BA}+0.0 \mathrm{mg} / \mathrm{L} \mathrm{Kin}+0.0 \mathrm{ml} / \mathrm{L}$ coconut milk (control)

(2) $3.0 \mathrm{mg} / \mathrm{L}(\mathrm{BA})$

(3) $3.0 \mathrm{mg} / \mathrm{L} \mathrm{BA}+5.0 \mathrm{ml} / \mathrm{L}$ (coconut milk)

(4) $5.0 \mathrm{mg} / \mathrm{L}(\mathrm{BA})$

(5) $5.0 \mathrm{mg} / \mathrm{L} \mathrm{BA}+5.0 \mathrm{ml} / \mathrm{L}$ (coconut milk)

(6) $3.0 \mathrm{mg} / \mathrm{L} \mathrm{Kin}$

(7) $3.0 \mathrm{mg} / \mathrm{L} \mathrm{Kin}+5.0 \mathrm{ml} / \mathrm{L}$ (coconut milk)

(8) $5.0 \mathrm{mg} / \mathrm{L} \mathrm{Kin}$

(9) $5.0 \mathrm{mg} / \mathrm{L} \mathrm{Kin}+5.0 \mathrm{ml} / \mathrm{L}$ (coconut milk)

\subsection{Statistical Analysis and Experimental Design}

A complete randomize design was used. Data obtained were subjected to analysis of variance and the means of treatment were compared using least significant differences (L.S.D.) test as outlined by Snedecor and Cochran (1972).

\subsection{Data Recorded}

After 4 weeks, data from culture media were collected as follows:

(1) Average length of shoots (cm).

(2) Average number of shoots per explant.

(3) Average number of leaves.

\subsection{Biochemical and Physiological Measurements}

\subsubsection{Content of Photosynthetic Pigments}

Chlorophyll a $(\mathrm{Chl} a)$ and chlorophyll $\mathrm{b}(\mathrm{Chl} b)$ contents were determined spectrophotometrically according to Metzner et al. (1965):

Chlorophyll $a(\mu \mathrm{g} / \mathrm{ml})=10.3 \times \mathrm{E}_{663}-0.918 \times \mathrm{E}_{644}$

Chlorophyll $b(\mu \mathrm{g} / \mathrm{ml})=19.7 \times \mathrm{E}_{644}-3.87 \times \mathrm{E}_{663}$

These pigment fractions finally, were calculated as fresh weight $(\mathrm{mg} / \mathrm{g})$. 


\subsubsection{Total Anthocyanin Determination}

Anthocyanin total content in the extracts was measured according to the described procedure by Alberto and Rabino (1975) after anthocyanin extraction with methanol supplemented with $\mathrm{HCl} 1 \%$, and centrifugation, absorbance was determined at 530 and $657 \mathrm{~nm}$. The formula $\mathrm{A}=\left(\mathrm{A}_{530}-0.25 \times \mathrm{A}_{657}\right)$ was applied to determine chlorophyll contribution and its degradation products to the absorption at $530 \mathrm{~nm}$. The Expression of anthocyanin content was as milligrams of Cyanidin-3-glucoside equivalent per mg FW.

\subsubsection{Total Phenolic Content}

The determinations of total phenolic were done using Folin-Ciocalteau reagents (Singleton \& Rossi, 1965). Standard solution of gallic acid $(2.0 \mathrm{mg} / \mathrm{ml})$ was prepared by accurately weighing $0.01 \mathrm{~g}$ and dissolving in $50 \mathrm{ml}$ of distilled water. Absorbance was measured at $765 \mathrm{~nm}$ after standing for one hour at room temperature. The results were expressed in $(\mathrm{mg} / \mathrm{g})$ gallic acid equivalents (GAE).

\section{Results and Discussion}

\subsection{Number of Shoots}

Data presented in Figures 1 and 2 showed the improving effect of several concentrations of Kin and BA with or without coconut water on production of shoots of $R$. officinalis. Almost all treatments increased shoots number per explant than the control and in almost cases it was insignificant increment. The highest shoots number 7 was obtained from MS medium with $5.0 \mathrm{mg} / \mathrm{L} \mathrm{Kin}$ as shown in Figure 5 when $3.0 \mathrm{mg} / \mathrm{L} \mathrm{Kin} \mathrm{combined} \mathrm{with} 5.0 \mathrm{ml} / \mathrm{L}$ coconut milk. Malik et al. (1992) also illustrated that applied kinetin induced more branching in lentil and, enhancing formation of multiple shoot by applying cytokinin in Pisum sativum. Li et al. (2017) investigated the effect of Kin added to MS medium cultured with Arabidopsis plants and concluded that Kin recognition could be affected by plant competition conditions that are the result of growing distance, and that the integrated performance of individuals were suitable to evaluate Kin interactions of plant species.

\subsection{Shoot Length}

The same figure showed that seedlings grown on MS medium including different levels of growth regulators showed significant differences. It is clear that the concentration of $5.0 \mathrm{mg} / \mathrm{L} \mathrm{BA}$ significantly induced the shortest shoots of $R$. officinalis $(1.6 \mathrm{~cm})$. However, inclusion of $3.0 \mathrm{mg} / \mathrm{L} \mathrm{BA}$ in presence of coconut milk 5.0 $\mathrm{ml} / \mathrm{L}$ in the medium elongated the shoots significantly. Differences on shoot length happened because different genotype gives various results on MS medium with numerous levels of plant growth regulator Shimelis et al. (2014). The difference is also due to variation of genotype and the number of days taken for culturing Sharma (2005). Addition of Coconut water increased the frequency of explants showing shoot regeneration, and elongation growth. Coconut water provides nutrients and is also a source of essential vitamins and growth hormones like zeatin ( $\gamma$-alyl aminopurine), and inositol besides reducing nitrogen compounds Mondal et al. (2015).

\subsection{Number of Leaves}

Highest number of leaves (29.3 leaves) was observed in culture medium modified with $3.0 \mathrm{mg} / \mathrm{L}$ BA in presence of $5.0 \mathrm{ml} / \mathrm{L}$ coconut milk ml/L. On the other hand $5.0 \mathrm{mg} / \mathrm{L} \mathrm{BA}$ gave a remarkable significant reduction of leaf number 4 as shown in Figure 1. Razdan (2003) concluded that the medium supplemented with $25 \%$ coconut water only supported viability, shooting; shoot elongation, rooting, root elongation and leaf formation. Coconut water as an organic substance in culture media had significant effect on shoots production and growth. Ge et al. (2004) reported the presence of zeatin-O-glucoside and dihydrozeatin-O-glucoside, a cytokinin in coconut water.

\subsection{Total Phenolic Content}

Figures 1 and 2 show that the treatment of $3.0 \mathrm{mg} / \mathrm{L} \mathrm{BA}$ enhanced the content of total phenolic to $(10.45 \mathrm{mg} / \mathrm{g})$ compared with all other treatments except control which achieved $(9.87 \mathrm{mg} / \mathrm{g})$. The same result $(9.87 \mathrm{mg} / \mathrm{g}) \mathrm{was}$ also achieved from the level of $5.0 \mathrm{mg} / \mathrm{L} \mathrm{BA}$ in absence of coconut milk. However, the level of $5.0 \mathrm{mg} / \mathrm{L} \mathrm{Kin}+$ $5.0 \mathrm{ml} / \mathrm{L}$ (coconut milk) gave a significant reduction of total phenolic content $(2.91 \mathrm{mg} / \mathrm{g})$. The effect of benzyladenisne on the phenolic content was reported by Abdel-Al et al. (1988) who showed that cytokinins increased phenolic content in cotton plants. 


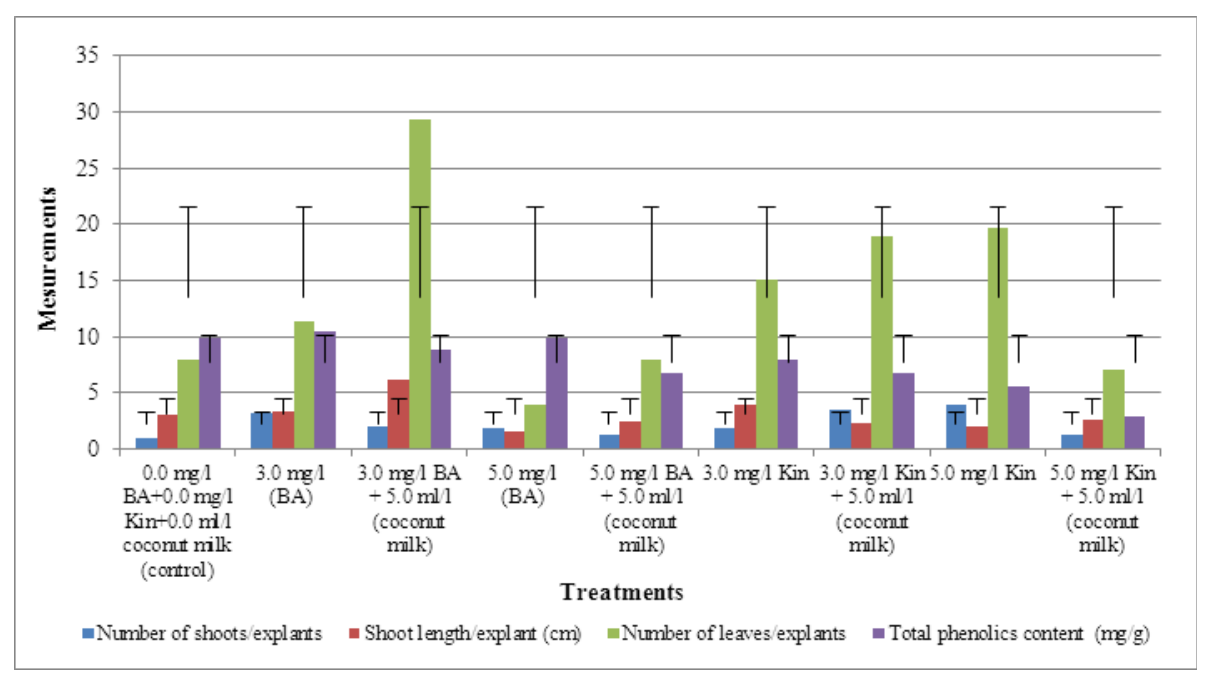

Figure 1. Effect of growth regulators on growth performance and total phenolics content of $R$. officinalis shoot

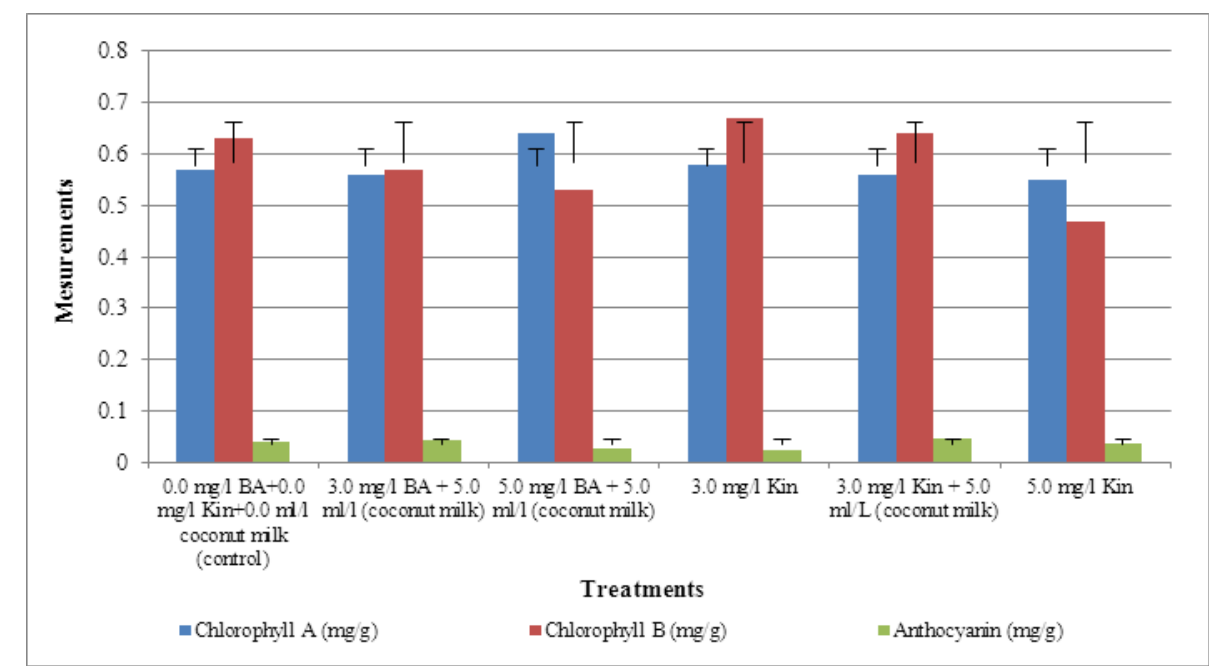

Figure 2. Effect of growth regulators on chlorophyll A, chlorpphyll B and, anthocyanin content of $R$. officinalis shoots

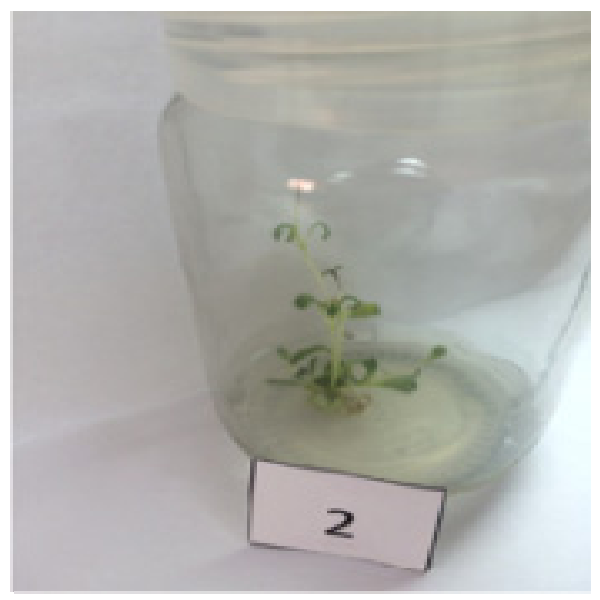

Figure 3. The effect of Kin and BA in presence of coconut water on shoot elongation 


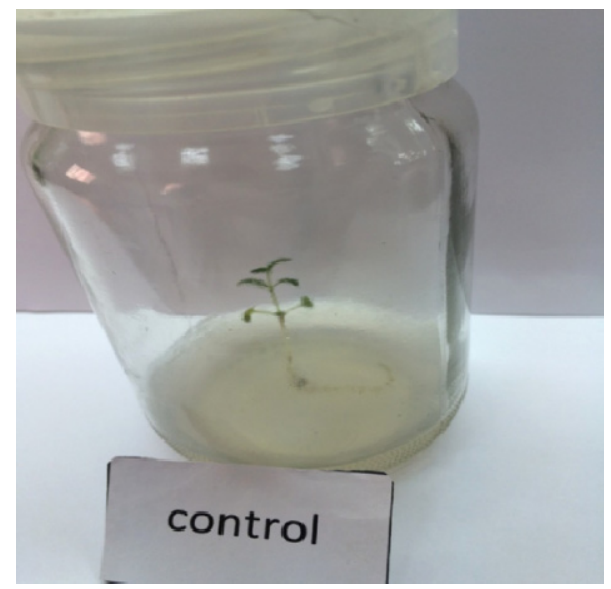

Figure 4. The untreated seedling

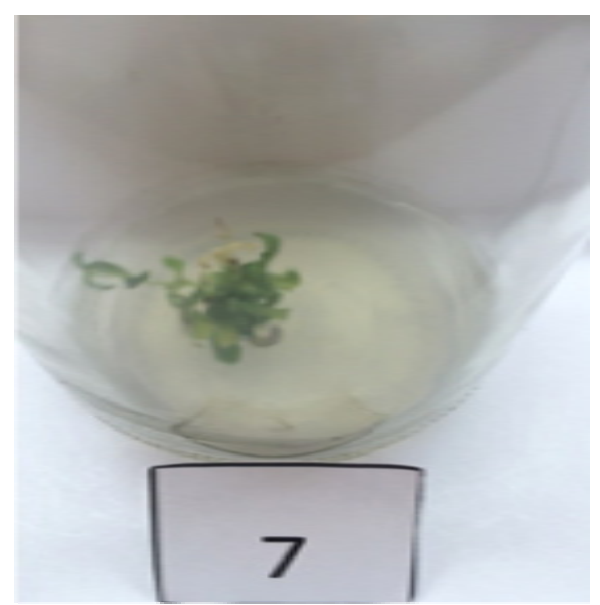

Figure 5. The effect of Kin on shoots formation

Data in Figure 2 showed that there were not significant differences between all treatments concerning chlorophyll a and chlorophyll $\mathrm{b}$ content of $R$. officinalis shoots. Anthocyanin content increased significantly $0.045 \mathrm{mg} / \mathrm{g}$ when Kin was $3.0 \mathrm{mg} / \mathrm{L}$ in the presence of coconut milk $5.0 \mathrm{ml} / \mathrm{L}$ followed by $0.043 \mathrm{mg} / \mathrm{g}$ anthocyanin obtained from $3.0 \mathrm{mg} / \mathrm{L}$ BA with $5.0 \mathrm{ml} / \mathrm{L}$ coconut milk. The presence of Kin in the level of 3.0 $\mathrm{mg} / \mathrm{L}$ gave the lowest content of anthocyanin $0.022 \mathrm{mg} / \mathrm{g}$. BA appeared to store the potential of anthocyanin production by subsequent subculture and also gave small reduction of callus growth. Similar results were obtained in the wild Vaccinium bahalae suspension cultures when the ability of anthocyanin production was restored as $20 \mu \mathrm{M}$ BA was introduced to culture medium as a substitution of Kin (Yemin et al., 1998). This report confirms the reverse relation between anthocyanin production and cell growth. There is a different phytohormone combination which stimulates the production of anthocyanin in several plants. Largado-Valler (2016) concluded that in the absence of BA in the culture medium anthocyanin production can be neglible. Anthocyanins are secondary metabolites in higher plants which contribute to the colors of fruits and flowers. They are, water soluble glucosides of anthocyanidins vacuolar pigments that appear purple, red or blue due to $\mathrm{pH}$. They belong to flavonoids synthesized by phenylpropanoid pathway. They spread in all tissues of higher plants, including flowers, leaves, roots, and stems (Hershey, 2001).

\section{Conclusion}

The level of $5.0 \mathrm{mg} / \mathrm{L}$ Kin gave the highest number of shoots/explants., Tallest shoots and the highest numbers of leaves were obtained in $3.0 \mathrm{mg} / \mathrm{L}$ BA with $5.0 \mathrm{ml} / \mathrm{L}$ coconut water. The highest total phenol content obtained from the level of $3.0 \mathrm{mg} / \mathrm{L} \mathrm{BA}$. On the other hand, coconut water at $5.0 \mathrm{ml} / \mathrm{L}$ with $\mathrm{Kin} 3.0 \mathrm{mg} / \mathrm{L}$ achieved the highest anthocyanin content. Concerning chlorophyll a and chlorophyll b, all previous treatments gave non-significant increment. 


\section{References}

Abdel-Al, M. H., Ismail, M. S., Azab, A., \& Ahmed, F. (1988). Response of three Egyptian cotton varieties to some micronutrient applications. Agric.Res.Rev., 65, 1-10.

Alberto, L., \& Rabino, M. I. (1975). Photocontrol of Anthocyanin Synthesis IV. Dose dependence and reciprocity relationships in anthocyanin synthesis. Plant Physiol., 56, 351-355. https://doi.org/10.1104/ pp.56.3.351

Bilto, Y., \& Alabdallat, N. G. (2015). In Vitro and in Vivo Antioxidant Related Effects of Rosemary (Rosmarinus Officinalis L.) Extracts in Humans. American Journal of Clinical and Experimental Medicine, 3(5), 213-221. https://doi.org/10.11648/j.ajcem.20150305.13

Bozin, B., Mimica-Dukic, N., Bogavac, M., Suvajdzic, L., Simin, N., Samojlik, I., \& Couladis, M. (2008). Chemical composition, antioxidant and antibacterial properties of Achillea collina Becker ex Heimerl s. I. and A. pannonica Scheele essential oils. Molecules, 13(9), 2058-2068. https://doi.org/10.3390/molecules

Eilyad, I., Parviz, K., Mohammad, T., \& Reza, F. (2012). Antimicrobial effects of rosemary (Rosmarinus officinalis L.) essential oils against Staphylococcus spp. African Journal of Microbiology Research, 6(23), 5039-42. https://doi.org/10.5897/AJMR12.741

Ge, L. Y. J., Yong, W. H., Tan, S. N., Yang, X. H., \& Ong, E. S. (2004). Analysis of some cytokinins in coconut (Cocos nucifera L.) water by micellar electro kinetic capillary chromatography after solid-phase extraction. Journal Chromatography, 1048(1), 119-26. https://doi.org/10.1016/S0021-9673(04)01186-0

Hershey, D. R. (2001). Correction (concerns celery leafstalk misidentification as stem). American Biology Teacher, 63(8), 554. https://doi.org/10.1662/0002-7685(2001)063[0554:C]2.0.CO;2

Huang, M. T., Ho, C. T., Wang, Z. Y., Ferraro, T., Lou, Y. R., Stauber, K., ... Conney, A. H. (1994). Inhibition of skin tumorigenesis by rosemary and its constituents carnosol and carnosic acid. Cancer Res., 54, 701-708.

Jasim, A. J. (2017). Reversed phase high performance liquid chromatography method for quantification of antioxidants in fresh rosemary leaves. RJPBCS, 8(4), 1015.

Largado-Valler, D. A. (2016). In-Vitro Production of Anthocyanin in Sesbania grandiflora (Red Katuray) as Influenced by Varying Concentrations of 2,4-D and BA Added on MS Medium. American Journal of Plant Sciences, 7, 2297-2306. https://doi.org/10.4236/ajps.2016.715202

Li, J., Xu, X., \& Liang, T. (2017). Kin Interactions of Arabidopsis Based on the Integrated Performance of Plants. Journal of Resources and Ecology, 8(2), 185-190. https://doi.org/10.5814/j.issn.1674-764X.2017.02.009

Malik, K. A., \& Saxena, P. K. (1992). Thidiazuran induces high frequency shoot regeneration in chick pea and lentil. Aust. J. Plant Physiol., 19, 6731-740. https://doi.org/10.1071/PP9920731

Metzner, H., Rau, H., \& Senger, H. (1965). Untersuchungen zur Synchronisierbakeit einzelner Pigmentmangel-Mutanten von Chlorella. Planta, 65, 186-194. https://doi.org/10.1007/BF00384998

Mondal, S., Kumar, M., Ahirwar, M. K., Singh, M. K., \& Singh, R. P. (2015). effect of coconut water and ascorbic acid on shoot regeneration in banana variety dwarf Cavendish. Int. J. Bio-res. Env. Agril. Sci., 1(1), 65-69.

Murashige, T., \& Skoog, F. (1962). A revised medium for rapid growth and bioassays with tobacco tissue cultures. Physiol. Plant, 15(3), 473-497. https://doi.org/10.1111/j.1399-3054.1962.tb08052.x

Nourin, A., \& Humera, A. (2014). Primary and secondary somatic embryogenesis from leaf explants of rosemary (Rosmarinus officinalis Lamiaceae). Pak. J. Bot., 46(3), 903-909.

Okamura, N., Haraguchi, H., Hashmoto, K., \& Yagi, A. (1994). Flavonoids in Rosmarinus officinalis leaves. Phytochem., 37, 1463-1466. https://doi.org/10.1016/S0031-9422(00)90434-5

Razdan, M. K. (2003). Introduction to Plant Tissue (2nd ed., pp. 27-29). Qxford \& IBH Publishing Co. Pvt. Ltd., New Delhi.

Room, A. (1988). A Dictionary of True Etymologies (p. 150). Taylor \& Francis.

Saltan, F. Z., \& Ozaydin, O. (2013). Ethnobotany of Eskisehir and its environs. Pak. J. Bot., 45(SI), $207-214$.

Sharma, M. (2005). In vitro regeneration studies of sugarcane (pp. 24-32, MSc Thesis, Patiala, India). https://doi.org/10.4172/2329-8863.1000128 
Shimelis, D., Bantte, K., \& Feyissa, T. (2014). Interaction effects of 6-Benzylaminopurine and kinetin on in vitro shoot multiplication of two sugarcane (Saccharum officinarum L.) genotypes. Advances in Crop Science and Technology, 2(4), 1-5. https://doi.org/10.4172/2329-8863.1000143

Singleton, V. L., \& Rossi, J. A. (1965). Colorimetry of total phenolic with phosphomolybdic-phosphotungstic acid reagents. Am. J. Enol. Viticulture, 16, 144-158.

Snedecor, G. W., \& Cochran, W. G. (1972). Statistical methods (6th ed., p. 147). Ames, Iowa: Iowa State University Press.

Tokusoglu, O., \& Yildirim, Z. (2012). Effects of cooking methods on the anthocyanin levels and antioxidant activity of a local turkish sweetpotato [Ipomoea batatas (L.) Lam] cultivar hatay kirmizi: Boiling, steaming and frying effects. Turkish Journal of Field Crops, 17(1), 87-90.

Wang, W., Wu, N., Zu, Y. G., \& Fu, Y. J. (2008). Antioxidativeactivity of Rosmarinus officinalis L. essential oil compared to its main components. Food Chem., 108(3), 1019-1022. https://doi.org/10.1016/j.foodchem. 2007.11.046

Yemin, F., Smith, M. A. L., \& Pepin, M. F. (1998). Benzyle adenine restores anthocyanin pigmentation in suspension cultures of wild Vaccinium pahalae. Plant Cell Tis. Org. Cult., 452, 113-122.

\section{Copyrights}

Copyright for this article is retained by the author(s), with first publication rights granted to the journal.

This is an open-access article distributed under the terms and conditions of the Creative Commons Attribution license (http://creativecommons.org/Licenses/by/4.0/). 